\title{
I.UMIBUNG
}

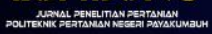

\section{PENGARUH LARUTAN GULA DENGAN PENAMBAHAN BERBAGAI KONSENTRASI LARUTAN ELEKTROLIT TERHADAP TINGKAT KESEGARAN KRISAN (Chrysanthemum sp) POTONG}

\author{
Eka Susila $^{1 *}$ dan Jonni ${ }^{1}$ \\ ${ }^{* 1}$ Program Studi Budidaya Tanaman Hortikultura, Jurusan Budidaya Tanaman Pangan \\ Politeknik Pertanian Negeri Payakumbuh \\ Korespondensi: ekasusila38@yahoo.com
}

\author{
Diterima : 08 Desember 2020 \\ Disetujui : $\quad 27$ Februari 2021 \\ Diterbitkan : 28 Februari 2021
}

\begin{abstract}
ABSTRAK
Bunga krisan merupakan salah satu jenis tanaman hias yang banyak diburu oleh para pecinta bunga. Perlu peningkatan kualitas bunga yang baik, sehingga keindahan dan kesegaran bunga potong krisan dapat dinikmati lebih lama dalam bentuk segar. Untuk kesegaran lebih lama digunakan tambahan zat penyegar diantaranya gula dan larutan elektrolit pada air rendaman. Tujuan penelitian untuk mengetahui tingkat kesegaran bunga krisan potong yang direndam dalam larutan gula dengan penambahan larutan elektrolit dengan konsentrasi berbeda dan mengetahui medium perendaman terbaik dalam mempertahankan tingkat kesegaran bunga krisan potong. Tempat pelaksanan di Laboratorium Hortikultura Politeknik Pertanian selama 6 bulan. Metode Rancangan Acak Lengkap (RAL), dengan 4 perlakuan dan 8 ulangan; A (air + gula $5 \mathrm{~g}$ ) sebagai control, B ( air + gula $5 \mathrm{~g}+$ larutan elektrolit $5 \mathrm{ml}$ ), C ( air + gula $5 \mathrm{~g}$ + larutan elektrolit $10 \mathrm{ml}$ ), dan D (air + gula $5 \mathrm{~g}+$ larutan elektrolit $15 \mathrm{ml}$ ). Variabel yang diamati lama kesegeran bunga, panjang tangkai bunga potong yang busuk, jumlah bunga yang masih mekar, layu, dan rontok. Data kuantitatif yang berbeda nyata diuji lanjut dengan LSD 5\%. Terdapat perbedaan tingkat kesegaran bunga krisan potong yang direndam dalam larutan gula dengan penambahan larutan elektrolit pada konsentrasi yang berbeda terhadap parameter (lama kesegaran bunga, panjang tangkai bunga yang busuk, jumlah bunga yang masih mekar, layu, dan rontok. Semakin tinggi konsentrasi larutan elektrolit yang diberikan, semakin memberikan tingkat kesegaran bunga yang lebih lama. Larutan gula yang ditambahkan larutan elektrolit $15 \mathrm{ml}$ merupakan konsentrasi terbaik dalam mempertahankan tingkat kesegaran bunga krisan potong.
\end{abstract}

Kata Kunci: Bunga potong, krisan, kesegaran, gula, larutan elektrolit

\begin{abstract}
Chrysanthemum is one type of ornamental plants that are hunted by many flower lovers. Need to improve the quality of flowers, like beauty and freshness of chrysanthemum flowers can longer in the fresh form. For longer freshness, fresheners are added, including sugar and electrolyte solution(ionic drink) to the immersion water. The objectives of the study were 1) to determine the freshness level of cut chrysanthemum soaked in sugar solution with the addition of electrolyte solutions with different concentrations and to determine the best
\end{abstract}




\section{I.UMIBUNG}

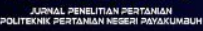

immersion medium in maintaining the freshness of cut chrysanthemum flowers. Place of implementation in the Horticultural Laboratory of Agricultural Polytechnic for 6 months, with completely randomized design method. Using 4 treatments and 8 replications: A (water $+5 g$ sugar (Control), B (water $+5 g$ sugar + electrolyte solution $5 \mathrm{ml})$, C. (water $+5 \mathrm{~g}$ sugar + electrolyte solution $10 \mathrm{ml}), \mathrm{D}$ (water $+5 \mathrm{~g}$ sugar + electrolyte solution $15 \mathrm{ml})$. Variables observed were length of flower freshness, length of rotten cut flower stalk, number of flowers that were still in bloom, withered and fell out. Significantly different quantitative data were further tested with 5\% LSD. There are differences in the level of freshness of cut chrysanthemum flowers soaked in sugar solution with the addition of electrolyte solution at different concentrations of parameters (length of freshness of flowers, length of rotten flower stalks, number of flowers that still bloom, wither and fall). The higher the concentration of sugar given, the more the level of freshness provides a longer flower. The concentration of $5 \mathrm{~g}$ sugar solution and electrolyte solution $15 \mathrm{ml}$ is the best concentration in maintaining the freshness of cut chrysanthemum flowers.

\section{Keywords: cut flower, chrysanthemum, freshness, sugar, electrolyte solution}

\section{PENDAHULUAN}

Krisan (Chrysantemum sp) merupakan tanaman bunga hias berupa perdu dengan sebutan lain Seruni atau Bunga Emas (Golden Flower) berasal dari dataran Cina. Bunga krisan adalah sejenis tumbuhan berbunga yang sering ditanam sebagai tanaman hias pekarangan atau bunga petik.Bunga krisan juga merupakan salah satu jenis tanaman hias yang banyak diburu oleh para pecinta bunga. Kepopuleran krisan disebabkan karena bunganya yang beraneka ragam. Menurut Sanjaya (1994), krisan mempunyai nilai jual dan estetika yang tinggi. Tanaman krisan merupakan tanaman perdu yang hidup musiman. Di Indonesia, bunga krisan tergolong cukup populer karena sering digunakan untuk penghias atau dekorasi ruang, biasa juga digunakan sebagai bahan pembuatan karangan bunga.

Peningkatan kualitas bunga yang baik menjadikan keindahan dan kesegaran bunga potong krisan dapat dinikmati lebih lama. Hal tersebut merupakan hal yang sangat didambakan, terlebih untuk digunakan dalam jangka waktu yang lama. Permintaan cukup banyak terutama bagi hotel, sangat memerlukan bunga krisan untuk penghias dan penyegar ruangan. Namun kendala yang sering dihadapi adalah kesegaran bunganya sangat singkat. Krisan merupakan tanaman hari pendek dan siklus hidupnya pun relatif singkat sebagai tanaman annual (Rukmana,1997).

Mutu bunga potong dapat dilihat dari penampilan kesegaran bunga, masa kesegaran bunga merupakan komponen utama penentu mutu bunga potong potong. Masa kesegaran bunga potong dihitung sejak bunga dipanen hingga menjadi layu yang ditandai oleh 


\section{I.UMIBUNG}

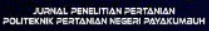

terkulainya atau mengerutnya jaringan akibat sifat-sifat elastis dan menurunnya tegangan turgor (Ariyanto, et al. 2018). Salah satu upaya untuk mempertahankan kualitas dan memperpanjang masa kesegaran bunga selama pemasaran atau pajangan adalah dengan pemberian larutan perendam. Umumnya larutan perendam terdiri dari air, gula (sukrosa), bakterisida, dan antibiotik (Zagory and Reid, 1986). Untuk menjaga mutu bunga potong dapat dilakukan dengan menggunakan larutan gula yang bahan bakunya berasal dari gula putih.

Gula sangat baik untuk meningkatkan kesegaran bunga potong, begitu juga dengan larutan yang mengandung gula seperti air kelapa. Menurut penelitian yang dilakukan oleh Adi (2012), penggunaan air kelapa dengan konsentrasi 60\% dan larutan gula dengan konsentrasi 10\% dapat mempertahankan kesegaran bunga mawar potong. Larutan air kelapa mengandung protein, lemak, mineral, karbohidrat, dan vitamin (Rukmana, 2003).Hormon sitokinin pada air kelapa dapat menunda senesen pada tingkat sel dan jaringan tanaman (Iriani, 2009).Kandungan karbohidrat dan hormone sitokinin yang ada pada air kelapa berguna sebagai sumber energi dan penunda senesen pada bunga potong agar dapat lebih lama dalam mempertahankan kesegarannya. Larutan gula merupakan sumber energi bagi bunga potong setelah pasca panen. Menurut Holstead (1985); Amiarsi dan Tejasarwana (2011), gula berfungsi sebagai sumber makanan bagi bunga.

Sukrosa atau dekstrosa merupakan jenis gula yang sering digunakan. Ditambahkan oleh Salinger (1985), jaringan tumbuhan membutuhkan gula untuk menjalankan fungsi vitalnya, terutama respirasi. Sukrosa dalam larutan perendam berperan sebagai bahan baku respirasi untuk menghasilkan energi yang akan digunakan dalam proses kehidupan sehingga kesegaran bunganya lebih lama. Pemakaian sukrosa pada konsentrasi yang tinggi sering menyebabkan tumbuhnya bakteri dan terbentuknya lendir, sehingga menghambat penyerapan larutan oleh tangkai bunga (Larsen dan Folich, 1969 dalam Astawa, 2003).Untuk menghambat pertumbuhan bakteri dapat dilakukan dengan memberi asam sitrat, karena asam sitrat berperanan sebagai antibiotik. Selain itu asam sitrat dalam larutan perendam dapat menurunkan $\mathrm{pH}$ larutan sehingga dapat diserap secara optimal oleh tangkai bunga (Prabawati, 2001).

Beberapa hasil penelitian telah direkomendasikan bahwa pemberian larutan perendam dapat meningkatkan pemekaran dan memperpanjang masa kesegaran bunga potong krisan (Tyas, 2012; Amiarsi et al.. 2000; Sabari et al., 1997; Sacalis,1993; Halevy dan Mayak, 


\section{I.UMIBUNG}

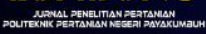

1981). Zat-zat yang merupakan komposisi dari larutan elektrolit (seperti minuman isotonic yang mengandung gula) antara lain adalah air, gula, asam sitrat, natrium sitrat, natrium klorida, kalium klorida, kalsium laktat, magnesium karbonat dan perisasitrus (http://www.pocari sweat.co.id). Untuk meningkatkan lama kesegaran pada bunga krisan potong, maka diberikan tambahan larutan gula dan larutan elektrolit. Tujuan penelitian adalah 1) untuk mengetahui tingkat kesegaran bunga krisan potong yang direndam dalam larutan gula dengan penambahan larutan elektrolit dengan konsentrasi berbeda, dan 2) mengetahui medium perendaman terbaik dalam mempertahankan tingkat kesegaran bunga krisan potong.

\section{METODE PENELITIAN}

Penelitian dilaksanakan di Laboratorium Hortikultura Politeknik Pertanian Negeri Payakumbuh. Bahan yang digunakan dalam penelitian ini adalah bunga krisan potong, gula pasir, larutan elektrolit (minuman isotonic yang dijual bebas di toko makanan), label dan kertas.

Metode penelitian menggunakan Rancangan Acak Lengkap (RAL) yang terdiri atas empat perlakuan dengan delapan ulangan. Tanaman krisan potong yang di gunakan dari lahan Politeknik Pertanian Negeri Payakumbuh. Pelaksanaan uji tingkat kesegaran krisan potong dengan perlakuan gula putih dan larutan elektrolit dengan konsentrasi berbeda yang diberikan pada media perendaman bunga potong. Empat perlakuan tersebut sebagai berikut :
A. Air + Gula $5 \mathrm{~g}$ (Kontrol)
B. Air + Gula $5 \mathrm{~g}+$ larutan elektrolit $5 \mathrm{ml}$
C. Air + Gula $5 \mathrm{~g}+$ larutan elektrolit $10 \mathrm{ml}$
D. Air + Gula $5 \mathrm{~g}+$ larutan elektrolit $15 \mathrm{ml}$

Semua alat yang akan digunakan terlebih dahulu disterilkan. Gelas ukur $300 \mathrm{ml}$ dibersihkan dari debu. Masukan air sebanyak $250 \mathrm{ml}$ pada masing-masing gelas ukur. Timbang gula pasir menggunakan timbangan analitik sebanyak 5 gram, masukan ke dalam gelas ukur yang sudah terisi air, aduk sampai homogen. Selain perlakuan kontrol, masukan larutan elektrolit sesuai perlakuan pada masing-masing gelas ukur (perlakuan B, C dan D). Potong ujung pangkal tangkai bunga krisan dengan kemiringan $45^{\circ}$, masukan tiap-tiap satu tangkai pada masing-masing perlakuan. Berikan label pada bunga yang akan diamati. Panjang bunga yang dipotong lebih kurang $20 \mathrm{~cm}$. 


\section{I.UMIBUNG}

Variabel yang diamati dan diukur dalam pengamatan utama yaitu:

- Lama kesegaran bunga (di hitung mulai hari ke-2 sampai hari ke- 8)

- Panjang tangkai bunga potong yang busuk(tangkai bunga yang busuk pada hari ke-8)

- Jumlah bunga yang masih mekar (di hitung mulai hari ke-2)

- Jumlah bunga yang layu (di hitung mulai hari ke-2)

- Jumlah bunga yang rontok (di hitung mulai hari ke-2)

\section{HASIL DAN PEMBAHASAN}

\section{Lama Kesegaran Bunga (mulai hari ke-2 sampai hari ke-8)}

Lama kesegaran bunga potong dapat dilihat dari bunga masih dalam keadaan segar sampai layu saat direndam dalam larutan gula. Dari hasil penelitian menunjukkan bahwa pemberian campuran gula dan larutan elektrolit mampu mempertahan umur kesegaran bunga krisan potong dibandingkan dengan perlakuan kontrol yang hanya direndam dengan larutan aquades ditambah gula sebanyak 5 gram.

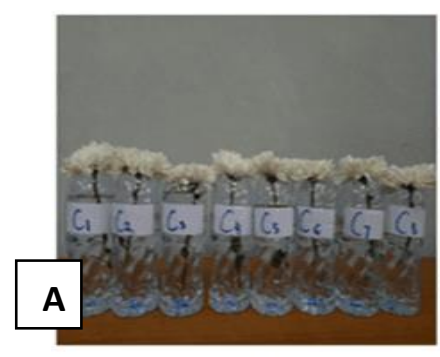

Umur 2 hari

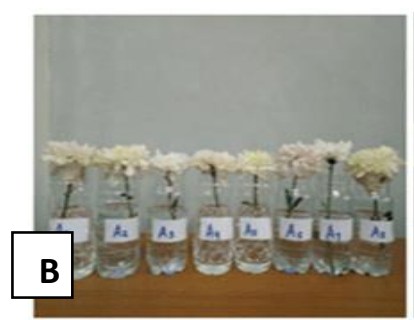

Umur 2 hari

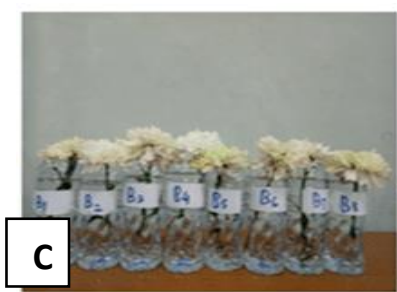

Umur 2 hari

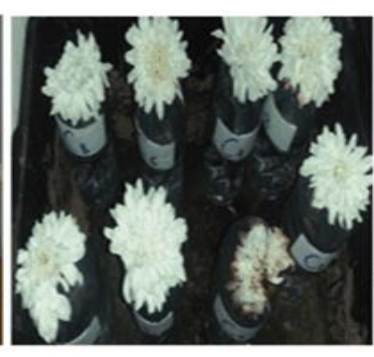

Umur 4 hari

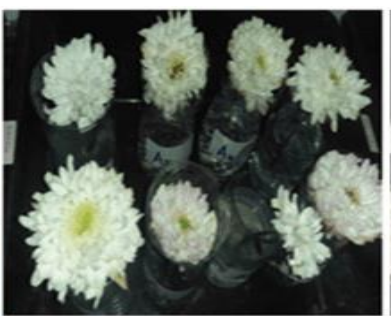

Umur 4 hari

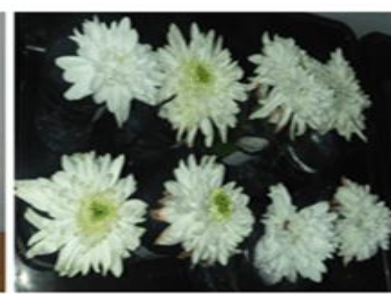

Umur 4 hari

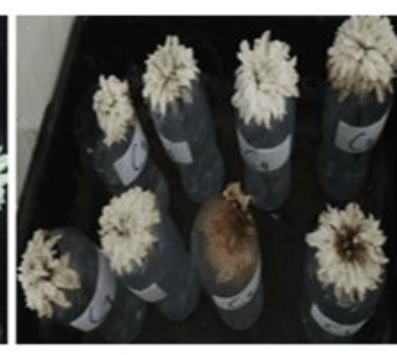

Umur 8 hari

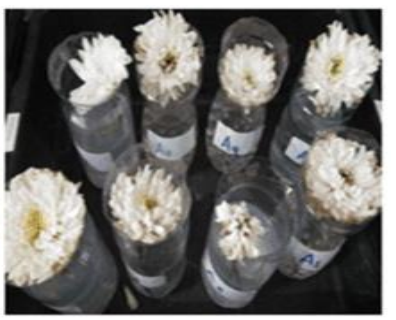

Umur 8 hari

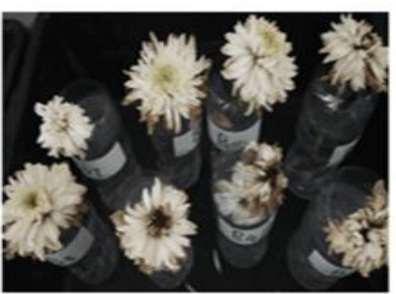

Umur $\mathbf{S}$ hari 


\section{I.UMIBUNG}

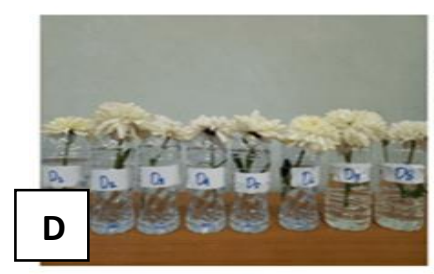

Umur 2 hari

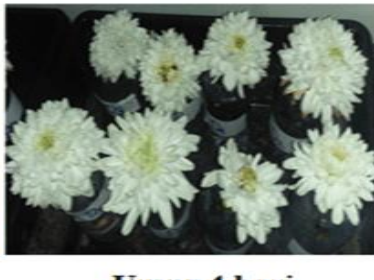

Umur 4 hari

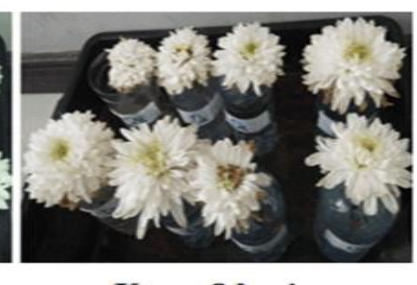

Umur $\mathbf{S}$ hari

Gambar 1.Tingkat kesegaran bunga potong krisan umur 2,4 dan 8 hari

Keterangan; $\mathrm{A}=$ air + gula $5 \mathrm{~g}$ (control), $\mathrm{B}=$ air+gula $5 \mathrm{~g}+$ larutan elektrolit $5 \mathrm{ml}, \quad \mathrm{C}=$ air + gula $5 \mathrm{~g}+$ larutan elektrolit $10 \mathrm{ml}), \mathrm{D}=$ air + gula $5 \mathrm{~g}+$ larutan elektrolit $15 \mathrm{ml}$.

Bunga potong masih melakukan proses biologis seperti respirasi dan transpirasi seperti ketika belum dipotong. Kesegaran bunga terbatas pada ketersediaan cadangan makanan dan air pada jaringan organ tumbuhan sehingga perlu asupan nutrisi dan air yang cukup dari luar sebagai bentuk usaha memepertahankan kesegaran. Upaya mempertahankan kesegaran bunga dilakukan dengan pengasaman larutan, penambahan zat pengatur tumbuh, bakterisida ataupun fungisida, dan zat nutrisi seperti gula (Ahyana, 2015).

Dari Gambar 1 terlihat bahwa pengamatan kesegaran bunga potong yang dimulai pada hari ke-2 sampai hari ke- 8, terlihat kesegaran bunga potong dengan perlakuan D (air+ gula 5 g+ larutan elektrolit $15 \mathrm{ml}$ ) masih dalam keadaan segar pada pengamatan hari ke-8. Artinya, perlakuan D memberikan tingkat kesegaran bunga potong tertinggi dibandingkan pada perlakuan lainnya (A, B, dan C). Menurut Amiarsi dan Tejasarwana (2011), larutan yang mengandung gula berperan sebagai energi metabolisme pada tumbuhan salah satunya dalam proses respirasi dimana gula dirubah menjadi energi sehingga bunga tetap segar dan penambahan gula dapat menunda kelayuan. Larutan gula merupakan sumber energi bagi bunga potong setelah pasca panen serta berfungsi sebagai sumber makanan bagi bunga.

Larutan elektrolit adalah minuman isotonik yang memiliki kandungan elektrolit yang seimbang sehingga dapat diserap lebih cepat dan lebih baik jika dibandingkan dengan cairan perendam air putih biasa (http://www.Pocari sweat.co.id). Hal ini dapat mencegah terjadinya dehidrasi berat akibat penguapan pada bunga krisan potong. Oleh karena itu, pemberian larutan gula yang dicampur dengan larutan elektrolit membuat kesegaran bunga krisan potong lebih lama. Dalam hal ini, pemberian konsentrasi campuran larutan gula 5 g dengan larutan elektrolit $15 \mathrm{ml}$ memberikan lama kesegaran bunga lebih lama dibandingkan perlakuan lainnya dengan konsentrasi larutan elektrolit lebih rendah.

Dari penelitian ini dapat diketahui bahwa, semakin tinggi konsentrasi larutan yang digunakan (konsentrasi pekat) memberikan hasil terbaik jika dibandingkan dengan kontrol. 


\section{I.UMIRUNG}

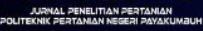

Fungsi gula sangat penting bagi bunga potong untuk menjaga tekanan osmotik sehingga penyerapan air berjalan dengan baik. Menurut Chintya (2016), semakin lama bunga dapat mempertahankan kesegarannya semakin banyak sel-sel dan jaringan pada bunga yang masih aktif sehingga semakin tinggi kemampuan daya serap air dan nutrisinya, sehingga proses transpirasi dan respirasi dapat berjalan dengan baik. Menurut Ariyanto, et al., (2018), semakin cepat bunga layu disebabkan oleh rendahnya keterserapan larutan pada bunga potong yang berkaitan dengan lama kesegaran bunga potong. Hal tersebut disebabkan penguapan yang terjadi pada bunga potong tidak diimbangi dengan penyerapan air yang cukup sehingga mengakibatkan bunga potong menjadi layu karena semakin rendah penyerapan larutan. Oleh sebab itu dapat mengakibatkan tingkat lama kesegaran bunga potong akan semakin rendah.

\section{Panjang Tangkai Bunga Potong yang Busuk (cm)}

Pembusukan yang terjadi pada tangkai bunga biasanya disebabkan oleh adanya perkembangan mikroba ditandai dengan kekeruhan yang terjadi pada larutan perendam, adanya lendir, dan pembusukan pada batang. Banyak bakteri yang ada dalam larutan pengawet mengakibatkan tertutupnya jaringan pada tangkai bunga sehingga larutan atau air yang diserap oleh tangkai untuk proses respirasi tidak optimal, sehingga mengakibatkan kelayuan yang lebih cepat (Chintya, 2016).

Pertumbuhan mikroba dalam medium perendam ikut mempengaruhi metabolisme bunga. Menurut Salunkhe et al.,(1990) dalam Kurniawan (2011) bahwa aktivitas mikroba tinggi dalam medium perendam akan membentuk gas etilen yang tinggi pula, sehingga menyebabkan bunga potong krisan cepat layu dan gugur, dan kualitasnya menjadi rendah. Aktivitas mikroba tinggi juga akan menimbulkan kerusakan jaringan pada bunga potong krisan yang dapat menghambat translokasi air yang mengakibatkan turgor rendah, serta meningkatkan laju respirasi sehingga bunga potong krisan cepat layu dan gugur.

Tabel 1. Panjang tangkai bunga potong yang busuk $(\mathrm{cm})$

\begin{tabular}{lcccc}
\hline Perlakuan & A & B & C & D \\
\hline Rata-rata (cm) & $12,44 \mathrm{~A}$ & $11,25 \mathrm{AB}$ & $10,25 \mathrm{~B}$ & $9,84 \mathrm{~B}$ \\
\hline
\end{tabular}

Angka-angka pada baris yang diikuti oleh huruf besar yang sama, berbeda tidak nyata sesamanya menurut uji LSD pada taraf nyata $5 \%(\mathrm{KK}=12,68)$

Dari analisis statistik menunjukkan bahwa terdapat perbedaan yang nyata pemberian larutan gula dan elektrolit dengan kosentrasi berbeda terhadap tingkat kesegaran bunga 


\section{I.UMIBUNG}

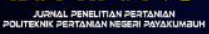

potong. Pada Tabel 1 terlihat bahwa rata rata perlakuan D (air + gula 5 g dan larutan elektrolit $15 \mathrm{ml}$ ) menunjukkan panjang tangkai bunga yang terpendek mengalami pembusukkan. Artinya perlakuan D merupakan perlakuan terbaik untuk menjaga kesegaran bunga potong lebih lama dibandingkan perlakuan lainnya (A,B, dan C) (Gambar 2).

Jika dilakukan uji lanjut menggunakan LSD dapat disimpulkan bahwa nilai rata-rata antara perlakuan $\mathrm{C}$ dan $\mathrm{D}$ tidak berbeda siginifikan sedangkan jika dibandingkan dengan ratarata perlakuan A berbeda signifikan dengan $\mathrm{C}$ dan $\mathrm{D}$.
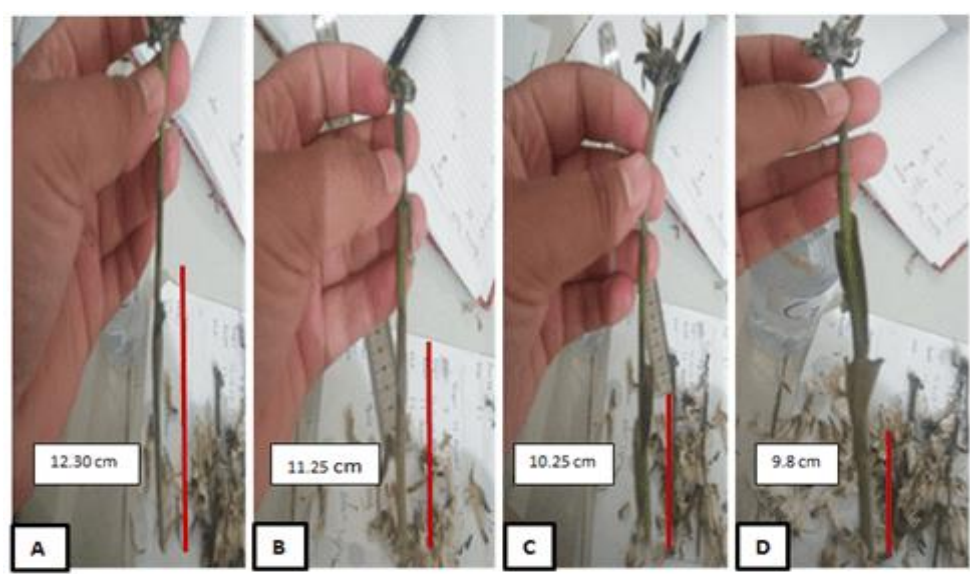

Keterangan;

$\mathrm{A}=$ Air + Gula $5 \mathrm{~g}$ (Kontrol)

$\mathrm{B}=$ Air + Gula $5 \mathrm{~g}+$ Larutan elektrolit $5 \mathrm{ml}$

$\mathrm{C}=$ Air + Gula $5 \mathrm{~g}+$ Larutan elektrolit $10 \mathrm{ml}$

$\mathrm{D}=$ Air + Gula $5 \mathrm{~g}+$ Larutan elektrolit $15 \mathrm{ml}$

Gambar 2. Tangkai bunga yang membusuk pada hari ke-8

Dari Gambar 2, dapat diketahui bahwa tangkai bunga yang membusuk tersebut disebabkan oleh mikroba-mikroba diantaranya seperti jamur. Jamur mengindikasikan medium perendam tersebut kurang efektif dalam mencegah perkembangan jamur yang dapat menggangguproses metabolisme dalam tangkai bunga. Adanya bakteri ditandai dengan berubahnya tingkat kekeruhan larutan perendam,terdapat lendir dan busuknya ujung tangkai bunga potong. Mikroba tersebut berasal dari bunga krisan itu sendiri ataupun dari lingkungan sekitar bunga (Zagory and Reid,1986; Amiarsi dan Tejasarwana, 2011).

Mikroba akan mudah tumbuh dalam medium perendam yang mempunyai sumber nutrien tinggi terutama glukosa. Mikroba memanfaatkan glukosa dalam medium perendam akan menginfeksisel-sel tanaman dengan merusak dinding sel. Aktivitas jamur dan bakteri tinggi pada perlakuan menimbulkan kerusakan jaringan pada tangkai bunga potong krisan sehingga menghambat penyerapan air yang pada akhirnya dapat menurunkan kualitas serta masa kesegaran bunga potong. Oleh karena itu, untuk membuat kesegaran bunga potong lebih lama, air perendamannya selain mengandung gula sebagai sumber makanan, juga dikombinasikan dengan germisida dan asam sitrat sebagai pengawet (Amiarsi dan Tejasarwana, 2011). 


\section{I.UMIPUNC}

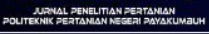

Dari Gambar 2, dapat diketahui bahwa komposisi medium yang terbaik yang ditandai dengan sedikitnya panjang tangkai bunga yang layu pada perlakuan D (campuran air+gula $5 \mathrm{~g}+$ larutan elektrolit $15 \mathrm{ml}$ ). Hal ini disebabkan karena larutan elektrolit yang ditambahkan mengandung asam sitrat. Semakin tinggi kosentrasi larutan elektrolit (15 ml), semakin mampu melindungi tangkai bunga dari kebusukkan. Menurut Prabawati (2001), kandungan asam sitrat yang ada pada larutan elektrolit mampu menghambat pertumbuhan bakteri, karena berperan sebagai antibiotik.

\section{Jumlah Bunga Mekar, Layu, dan Rontok (tangkai)}

Tabel 2. Jumlah bunga mekar, layu, dan rontok sampai hari ke-8

\begin{tabular}{|c|c|c|c|c|c|}
\hline Hari & Pengamatan & $\mathbf{A}$ & B & $\mathbf{C}$ & D \\
\hline \multirow{3}{*}{1} & Mekar & 8 & 8 & 8 & 8 \\
\hline & Layu & 2 & 0 & 1 & 0 \\
\hline & Rontok & 0 & 0 & 1 & 0 \\
\hline \multirow{3}{*}{2} & Mekar & 8 & 8 & 8 & 8 \\
\hline & Layu & 2 & 0 & 1 & 0 \\
\hline & Rontok & 0 & 0 & 1 & 0 \\
\hline \multirow{3}{*}{3} & Mekar & 8 & 8 & 8 & 8 \\
\hline & Layu & 3 & 0 & 1 & 0 \\
\hline & Rontok & 0 & 0 & 1 & 0 \\
\hline \multirow{3}{*}{4} & Mekar & 8 & 8 & 8 & 8 \\
\hline & Layu & 6 & 5 & 3 & 2 \\
\hline & Rontok & 0 & 0 & 0 & 0 \\
\hline \multirow{3}{*}{5} & Mekar & 2 & 2 & 7 & 8 \\
\hline & Layu & 7 & 6 & 3 & 4 \\
\hline & Rontok & 1 & 2 & 1 & 0 \\
\hline \multirow{3}{*}{6} & Mekar & 1 & 2 & 7 & 8 \\
\hline & Layu & 7 & 6 & 4 & 4 \\
\hline & Rontok & 1 & 2 & 1 & 0 \\
\hline \multirow{3}{*}{7} & Mekar & 1 & 1 & 7 & 8 \\
\hline & Layu & 7 & 7 & 4 & 4 \\
\hline & Rontok & 1 & 1 & 1 & 0 \\
\hline \multirow{3}{*}{8} & Mekar & 1 & 1 & 1 & 8 \\
\hline & Layu & 8 & 8 & 8 & 8 \\
\hline & Rontok & 1 & 2 & 1 & 0 \\
\hline
\end{tabular}

Pada Tabel 2, dapat diketahui pada hari ke-1 sampai ke-3, perlakuan A dan C mahkota bunga layu dan rontok. Pada hari ke 4-8 mahkota bunga pada semua perlakuan mengalami kerontokan. Sedangkan untuk perlakuan D tidak ada mahkota bunga yang rontok. 


\section{I.UMIBUNG}

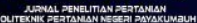

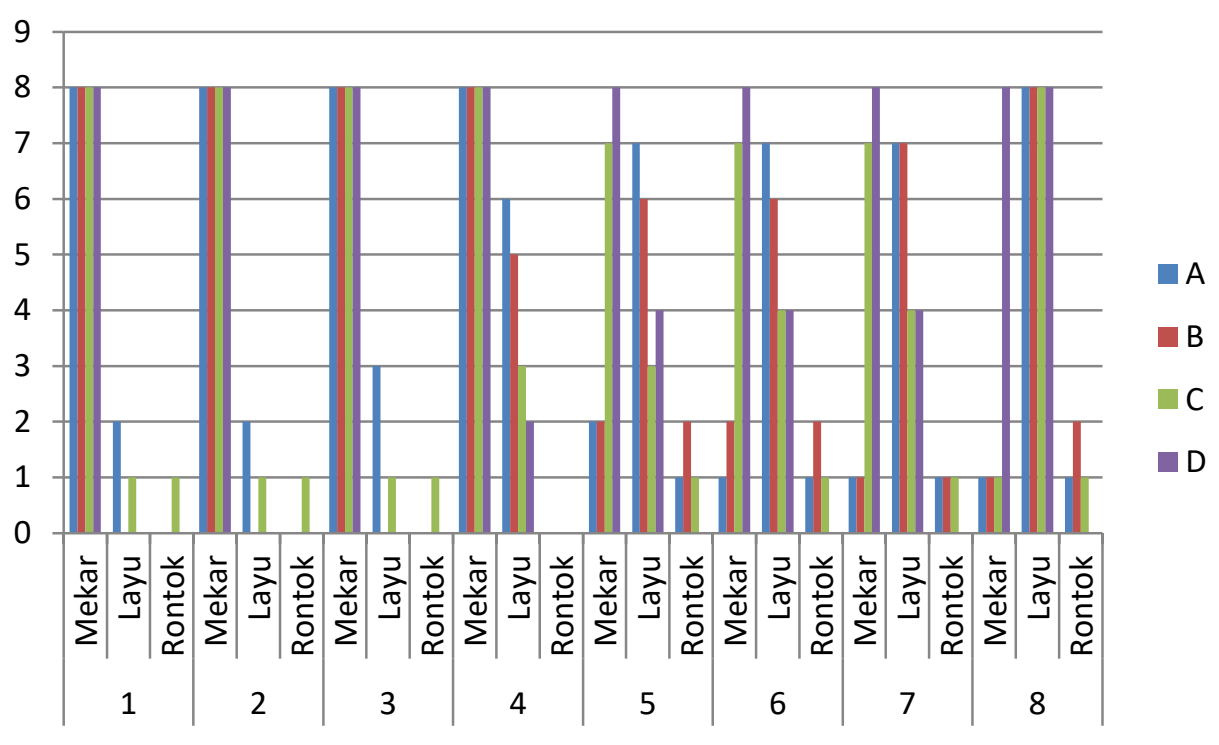

Gambar 3. Jumlah bunga mekar, layu, dan rontok sampai hari ke-8

Proses pelayuan dan kerontokan dari bunga dipercepat bila hilangnya air lebih banyak daripada penyerapan, sehingga menyebabkan tangkai bunga kekurangan air dan tekanan turgornya rendah akibatnya terjadilah plasmolisis. Adanya hubungan korelasi negatif antara persentase bunga layu dengan total larutan terserap, ini berarti semakin rendah larutan yang terserap oleh tangkai bunga maka persentase bunga layu semakin tinggi. Dari hasil penelitian ini juga dapat ditambahkan bahwa dengan adanya pertumbuhan mikroba seperti jamur yang tertinggi terdapat pada larutan A diikuti larutan B,C, dan D. Pertumbuhan jamur tersebut mengakibatkan terhambatnya penyerapan larutan oleh tangkai bunga sehingga menyebabkan bunga tersebut layu dan rontok.

\section{KESIMPULAN}

Kesimpulan dari penelitian ini diantaranya: 1) terdapat perbedaan tingkat kesegaran bunga krisan potong yang direndam dalam larutan gula dengan penambahan larutan elektrolit pada konsentrasi yang berbeda terhadap parameter (lama kesegaran bunga, panjang tangkai bunga yang busuk, jumlah bunga yang masih mekar, layu, dan rontok. Semakin tinggi konsentrasi larutan elektrolit yang diberikan, semakin memberikan tingkat kesegaran bunga yang lebih lama, 2) larutan gula yang ditambahkan larutan elektrolit $15 \mathrm{ml}$ merupakan konsentrasi terbaik dalam mempertahankan tingkat kesegaran bunga krisan potong. 


\section{I.UMIRUNG}

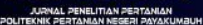

\section{REFERENSI}

Adi, Meika Moch. 2012. Pengaruh pemberian Larutan Kelapa (Cocos nucifera) dengan Penambahan Larutan Gula terhadap Kesegaran Bunga Mawar Potong (Rosa hybrida). Skripsi. Surakarta: Fakultas Keguruan dan Ilmu Pengetahuan. Universitas Muhammadiyah Surakarta.

Ahyana, B.A.H. 2015. Efek Gula Terhadap Kesegaran Bunga Potong Chrysanthemum sp. (Studi Empiris Sebagai Bahan Pengembangan Petunjuk Praktikum Fisiologi Tumbuhan). Artikel. FKIP Universitas Mataram.

Amiarsi, D., Yulianingsih, dan Murtiningsih. 2000. Penggunaan Larutan Perendam (Pulsing) dalam Mempertahankan Kesegaran Bunga Mawar Potong. J.Hort. 12(3): 178-183.

Astawa, I.N.G. 2003. Memperpanjang Kesegaran Bunga Mawar dalam Vas Dengan Pemberian Sukrosa dan Perak Nitrat ke dalam Larutan Perendam. Agritrop 22 (2): 73 $-76$

Amiarsi, D., dan Tejasarwana. 2011. Pengawet untuk Menjaga Kualitas Bunga Potong Mawar selama Penyimpanan. J. Hort. 21(3):274-279.

Ariyanto, E.R Mulyaningrum dan P. Rahayu. 2018. Pengaruh Ekstrak Jeruk Nipis dengan Larutan Gula Kelapa terhadap Keterserapan Larutan dan Lama Kesegaran Pada Bunga Potong Krisan. Jurnal Biologi dan Pembelajarannya, 5 (2) :32-37.

Chintya. U.D. 2016. Tingkat Kesegaran Bunga Krisan Potong yang Direndam dalam Campuran Air Kelapa dan Larutan Gula Pasir dengan Penambahan Ekstrak Buah Belimbing Wuluh. FKIP Universitas Muhammadiyah Surakarta.

Halevy, A.H. and S.Mayak. 1981. Senescence and Postharvest Physiology of Cut Flower Part 2. Horticulture Review.3:39- 143.

Holstead, C. L. 1985. Care and Handling of Flowers and Plants. USA : The Society of Americans Florist.

http://www.Pocari sweat.co.id.

Iriani, F. 2009. Formulasi Lengkap Larutan Pengawet Bunga Potong Anyelir (Dyanthus caryophillus). Jurnal Agrikultura.

Kurniawan, A.A.,T. Wardiyati, dan E.Nihayati. 2011. Pengaruh Komposisi Larutan Perendam dalam Memperpanjang Kesegaran Anggrek Potong Dendrobium. Fakultas Pertanian Universitas Brawijaya, Malang. http://elibrary.ub.ac.id. Diakses tanggal 26 Januari 2019.

Prabawati, S. 2001. Krisan awet 20 hari dengan "Gula Pasir". Trubus. Edisi Maret, Th. XXXII, No. 376. Hal. 100.

Rukmana, dan H. Rahmat. 2003. Aneka Olahan Kelapa. Yogyakarta : Kanisius

Rukmana dan H. Rahmat. 1997. Krisan. Penerbit Kanisius. Yogyakarta. 


\section{I.UMIBUNG}

Sabari, S.D., Yulianingsih, B. Trisna dan Sunarmani 1997. Komposisi Perendam untuk Menjaga Kesegaran Mawar Potong dalam Vas. Jurnal Hortikultura.7(3):818-828.

Sacalis, J.N.1993. Cut Flowers, Prolonging Freshness, Postproduction Care an Handing, 2nd ed. Ball. Publishing. Illionis.110p.

Sanjaya, L. 1994. Evaluasi Hasil Penelitian Tanaman Hortikultura dalam Pelita V Pusat Pengembangan dan Penelitian Hortikultura. Jakarta Hal 12.

Salinger, J. P. 1985. Commercial Flowers Growing. New Zealand : Butterworth of New Zealand.

Tyas, P.W. 2012. Pengaruh Larutan Sukrosa, Asam Sitrat, dan Ekstrak Daun Kemangi (Ocimum americanum L.) terhadap Pemekaran dan Masa Kesegaran Bunga Potong Anggrek Larat (Dendrobium phalaenopsis Fitzg). Skripsi. Fakultas Sains dan Matematika, Universitas Diponegoro. Semarang.

Zagori, D. and M.S. Reid. 1986. Evaluation the Role of Vase Microorganism in the Postharvest Life of Cut Flowers. Acta Horticulturae. 181:207 217. 